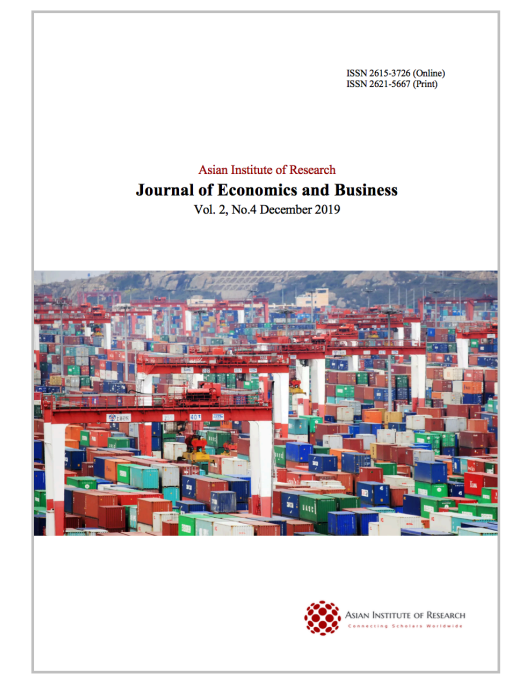

\title{
Journal of Economics and Business
}

\begin{abstract}
Nwakoby, Nkiru P., Okoye, Jane Frances, and Anugwu, Chika C. (2019), Effect of Organizational Culture on Employee Performance in Selected Deposit Money Banks in Enugu State. In: Journal of Economics and Business, Vol.2, No.4, 12131225.
\end{abstract}

ISSN 2615-3726

DOI: 10.31014/aior.1992.02.04.162

The online version of this article can be found at: https://www.asianinstituteofresearch.org/

Published by:

The Asian Institute of Research

The Journal of Economics and Business is an Open Access publication. It may be read, copied, and distributed free of charge according to the conditions of the Creative Commons Attribution 4.0 International license.

The Asian Institute of Research Journal of Economics and Business is a peer-reviewed International Journal. The journal covers scholarly articles in the fields of Economics and Business, which includes, but not limited to, Business Economics (Micro and Macro), Finance, Management, Marketing, Business Law, Entrepreneurship, Behavioral and Health Economics, Government Taxation and Regulations, Financial Markets, International Economics, Investment, and Economic Development. As the journal is Open Access, it ensures high visibility and the increase of citations for all research articles published. The Journal of Economics and Business aims to facilitate scholarly work on recent theoretical and practical aspects of Economics and Business. 


\title{
Effect of Organizational Culture on Employee Performance in Selected Deposit Money Banks in Enugu State
}

\author{
Nkiru P. Nwakoby ${ }^{1}$ Jane Frances Okoye ${ }^{2}$, Chika C. Anugwu ${ }^{3}$ \\ ${ }^{1,2,3}$ Department of Entrepreneurship Studies, Nnamdi Azikiwe University, Awka, Nigeria \\ Correspondence: thaddray4life@yahoo.com / nwakobyn@yahoo.co.uk
}

\begin{abstract}
This study determined the effect of organizational culture on employee performance in deposit money banks in Enugu State, Nigeria. Specifically, the study intent to: ascertain the extent bureaucratic culture has significant influence on employees' performance of deposit money banks and determine whether innovative culture has significant influence on employees' performance of deposit money banks. Survey research design was employed for this study. The data were collected through the questionnaires administered to the respondents. The formulated hypotheses were tested with regression analysis. The result shows that bureaucratic culture does not significantly affect employee performance of deposit money banks. Another finding is that innovative culture has significant affect employee performance of deposit money banks. The study therefore, recommended among other things that the management of deposit money banks should develop cultures that will enhance performance, having the interest of their customers and employees at heart.
\end{abstract}

Keywords: Organizational Culture, Employee Performance, Bureaucratic Culture and Innovative Culture

\section{INTRODUCTION}

The idea that organizations can have a culture that affects the performance of its employees started when scholars within the field of sociology responded to Max Weber's theory of bureaucracy (Nier, 2009). During the period of economic recession, the issues of maximizing output are essential to shareholders. Organization realizes that it is the employees that make businesses work and that the culture of an organisation connects employees to the organisation. This led in the idea that maximizing an employee's performance in organizations needs the execution of policies, practices, and procedures that match the employee's needs (Isa, Ugheoke \& Noor, 2016).

Although the writing on organisational culture and its alliance with organisational performance are wealthily varied, there is a small amount of study that really examines the concept of this connection. Culture has been set up as the main factor to be considered through in organisational life along with its positive impact on the success of the organizational performance (Durgadevi \& Vasantha, 2017). Because it is evolved through the organisation 
culture in array to sway the behaviour and attitude of the employees, organisational culture depends on the views and characteristics of the employees working in the organisation. In an effort to have a better understanding, many cultural typologies have been developed, because a particular type of culture produces a different outcome and the overall performance of an organisation is subject to the extent to which the values of the cultures are extensively shared (Ogbonna \& Harris, 2000). For instance, the competing value framework (CVF) classifies organisational culture into four cultural categories, such as clan, adhocracy, market, and hierarchy (Quinn \& Robert 2011; Tseng, 2010). The hierarchical culture has an unambiguous organisational structure, standardized policy and procedures, stringent control, and well-defined responsibilities. Gu, Hoffman, Cao, and Schniederjans (2014) classify organisational culture into four dimensions, such as leadership ability to take risks, tolerance, results-oriented, institutional collectivism, and positive work environment. Other researchers further narrow the organisational culture into three dimensions. For instance, Zehir, Ertosun, Zehir, and Müceldili (2011) classify organisational culture into competitive, bureaucratic, and community dimensions. Yiing and Ahmad (2009) divide the organisational culture into a supportive, innovative, and bureaucratic culture. Supportive culture is distinguished by unbiased, friendly, trusting, as well as shared behaviors. However, a study by Klehe and Anderson (2007) divided organisational culture into two categories, such as collectivism and individualism. This demonstrates that there is no one acceptable way of examining organisational culture. This is consistent with Schneider, Ehrhart, and Macey (2013), who claim no precise way of how organisational culture should be studied. It is emphasized that no one type of organisational culture is better than the other, and different types of culture are better for different workplaces, different corporate philosophies and different type of companies (Schneider, et al. 2013). Hence, it is better for an organisation to focus on the type of culture that will create a better performance (Iliuta, 2014).

Organizational culture is based on cognitive systems, which help to explain how employees think about and make a decision. Charles and Gareth (2009) argued that "organizational culture is the specific collection of values and norms that are shared by people and groups in an organisation. To them, the culture of the organisation control the way employees interact with each other and with stakeholders outside the organisation." This shows that the organisation's norms and values have a strong effect on all those who are attached with the organization. (Isa, Ugheoke \& Noor, 2016).

Many studies have also been carried out on organizational culture and employee performance; some of the studies found a significant positive effect between organizational culture and employee performance. Despite the above results, some researchers found a negative effect between organizational culture and employee performance. The results from the empirical studies are inconsistent and some are contradictory, ranging from positive to insignificant negative relationship. Besides, there is a limited study of this nature in the Nigerian banking sector and this created a gap in the literature which this study becomes significant. Based on this, the study, therefore, seeks to determine the effect of organisational culture on employee performance in deposit money banks in Enugu state. Specifically, the study intent to:

1. Ascertain the extent of bureaucratic culture has a significant effect on employees' performance of deposit money banks.

2. Determine if innovative culture has a significant effect on employees' performance of deposit money banks.

\section{REVIEW OF RELATED LITERATURE}

\section{Conceptual and Theoretical Framework}

\section{Organizational Culture}

Many definitions of organizational culture, but essentially these definitions refer to three approaches on references (Martins, 1992), namely: (i) Integration approach, states that every organization has one type of culture that coloring all the values and activities of its members. This approach emphasizes the consensus of all members of the organization to a dominant culture. (ii) Differentiation approach, emphasizing the sub-cultural consensus. In this approach, it is possible for every organization to have one or more sub-cultures that can still 
be divided into three, namely sub-cultures that are in line with corporate culture, sub-cultures that are different from corporate culture and sub-culture that are opposed to corporate culture. (iii) Fragmentation approach, in this approach, there is no consensus among members of the organization and there is no similarity or agreement of values adopted in the members of the organization. In other words the corporate culture does not exist, that there are personal values of members of the organization (Romi, 2018). According to Cambridge dictionary, culture can be defined as the way of life, especially the general customs and beliefs, of a particular group of people at a particular time.

Organizational culture, according to Mobley, Wang, and Fang (2005), is a less tangible factor that determines the source of competition outside quality, cost, technology, consumer service brand, etc. Organizational culture is introduced to all employees once they are recruited; this helps them to be acquainted with the organization and the happenings in the system (Fakhar, Zahid \& Muhammad 2012). According to Alvesson (2002), organizational culture is behavioural regularities, that guide policies on how to best workers and customers are to be treated. That is, the organizational climate gives an overall feeling, and this is portrayed in the physical layout, interaction process, and the ways employees conduct themselves. Organizational culture is the values, principles, traditions, and attitudes that affect the way members of an organization behave (Robbins, Odendaal, \& Roodt, 2007).

According to Kreitner and Kinicki (2005), culture has several functions in the organization. First, hold the key to the limits, meaning a culture of creating differences between one organizations to another. Second, create a cultural identity of members of the organization. Thirdly, culture helped create employee commitment to the organization that is greater than the individual interest. Fourth, culture improves the stability of the social system. Each organization is able to build and develop the culture of the organization in accordance with the demands of the external environment; the culture will have an effective and efficient to improve performance to meet the needs of stakeholders and existence.

The dimensions of organizational culture according to Schein (2014) consists of three dimensions, namely: a) External adaptation tasks, consisting of the mission, goals, basic facilities, and the measurement of success; b) Internal integration tasks consist of restrictions in the group, the placement status / power, and the relationships within the group; and c) Basic underlying assumptions consist of a relationship with the environment, the nature of the activities of employees, the nature of time, and the nature of the relationship between employees. According to Greenberg (2010), dimensions of organizational culture, that is: a) Company founder. Cultural organizations working can be traced, at least in part, on the company's founder. b) Experience with the environment. Cultural organizations often develop outside the organization's experience with the external environment; c) Contact with others. Organizational culture is also growing outside the contact between a group of individuals within the organization who came to share the interpretation of events and activities within the organization.

Furthermore, Robbins (2008) mentions the seven dimensions of organizational culture, namely: a) Innovation and risk-taking, namely the extent to which employees are encouraged to be innovative and take risks; $b$ ) Attention to details, namely the extent to which employees are expected to exhibit precision, analysis, and attention to detail; c) Orientation results, namely the extent to which the management focus on results rather than on the techniques and processes used to achieve those results; d) Orientation of people, namely the extent to which management decisions take into account the impact of the results of the employee; e) Orientation teams, namely the extent to which work activities are organized based on the team; f) Aggressiveness, namely the extent to which employees are aggressive and competitive; and g) Stability, namely the extent to which the organization's activities emphasize the maintenance of the status quo.

\section{Employee performance}

Employee performance is a record of the results obtained from the specific job functions for a certain period of employee (Bernardin and Russel: 2008) and according to Mathis and Jackson (2011) the employee's performance is something that has been done and not done by employee. John (2012) stated that the object of the 
performance appraisal evolved from an individual-centered approach moving towards employment (job centered) and finally centered on the target (objective centered). Individual-centered approach is evaluating the character or personal characteristics of an individual. Job centered approach is more focused on the behavioral approach. Finally, the approach shifted towards output orientation that person's performance ratings based on results (outputs). Employee performance appraisals are done properly in accordance with its function would benefit the company because it can improve performance.

The dimensions of the employee performance according to Dessler (2012) consists of five dimensions, 1) Quality of Work, is characteristic of a job that can show the level of needs and desires that are expected by a person; 2) The quantity of work, is the amount of work successfully completed by the employee in accordance with the job description in a specified period; 3) Supervision, is the attitude of giving landing a job or duty of superiors to subordinates who lack the knowledge and skills; 4) Presence, is the level of attendance of employees in the workplace; 5) Creation, is the attitude or activities to protect, maintain and allocate something. According to Bernardin and Russel (2008), the dimensions of employee performance consists of 1) Quality, which shows the level of the work process or the work that has been achieved from a job; 2) Quantity, which is the amount of product produced expressed in the currency, the number of production units, or the number of cycles of activities have been completed; 3 ) Timelines, namely the speed of a work that has been completed within a predetermined time; 4) Cost-Effectiveness i.e., the maximum level of use of the existing resources in doing a particular job; 5) Supervision, namely the extent to which an employee can complete the work without the need for supervision; 6) Interpersonal impact, that levels of the circumstances in which employees can create a comfortable atmosphere in work, confident, doing good, and work together with colleagues.

Business researchers and management scholars are mainly concerned in identifying the most significant definition of employee's performance. Even though employee's performance has become a common phenomenon in management studies and makes its definition and structure reliable and explicitly justified March and Sutton (1997). Additionally, as mentioned earlier, Anitha (2014) defined employee performance as the financial or non-financial outcome of the employee that has a direct link with both the performance of the organization and its success.

\section{Organization and employee performance}

Many organizational behavioral theorists believe that a good fit between employees and the organization is significant to performance. The linkage among organizational culture and performance has received great deal of attention from scholars in the field of organizational culture (Ogbonna and Harris, 2000). Stoica et al. (2004) asserted that the relationship between culture and performance is influenced by the way organizations search for and use information. Therefore, comprehending the correlation between organizational culture and employee's task performance is an important research subject because detections of various studies have demonstrated that an individual's work performance is a vital element toward the success of organizations (Shahzad et al.2013). A well-built organizational culture serves as a powerful tool to execute innovative ideas, influences employee's behaviors, and increases performance (Kim Jean Lee \& Yu, 2004). When an individual's values and organizational practices are well integrated, it will largely affect the level of individual and organizational output. The more employees identify that an organization provides uninterrupted learning, dialogue with employees, and has a well-connected system with good leadership, the more committed they will be to the organizational goals (Joo \& Lim, 2009; Joo \& Shim, 2010).

Possibly, employee's dissatisfaction with an organizational culture is the most important reason that causes poor performance and turnover in current organizations. Consequently, Silverthorne (2004) argues that the better the fit, the better the extent of job satisfaction, not considering the type of organizational culture. Following this, the literature suggests that organizations should pay attention to their culture and build suitable communication and capability to manage uncertainty and to achieve the needed organizational commitment (Cheung, Wong, \& Wu, 2011; Ezirim, Nwibere, \& Emecheta, 2012). 
In view of the above, different cultural practices have gained research attention. For instance, a study by Higgins and McAllaster (2002) opined that an innovative-supportive culture is obtained from values, an informed underlying belief structure in addition to strong daily practices. Accordingly, Detert, Schroeder, and Mauriel (2000) argue that the values of an organization serve as the foundation of cultures that promote process innovation that permit or hinder performance improvement. It is a system that allows innovation, necessitates a culture of discipline (for example, an attitude and practice that emphasizes the monitoring of quality to be aware of problems), and encourages creativity in the process of solving problems. A study by Silverthorne (2004) involving a sample of Taiwanese employees argues that a bureaucratic organization has a larger problem in sustaining employee job satisfaction than organizations that have an innovative or supportive culture; thus, emphasizing that an organization that has a bureaucratic culture result in the lowest level of job satisfaction.

A study by Ogbonna and Harris (2000) also established that competitive and innovative cultures had a direct relationship with employees' performance, while community and bureaucratic cultures had no direct relationship with performance. According to Damanpour and Gopalakrishnan (2001), effective innovation improves organizational effectiveness and responsiveness. However, despite the significant argument on innovative culture, other researchers argue that innovation-supportive culture remains a difficult and unstructured phenomenon (Higgins \& McAllaster, 2002). An innovative culture poses great challenges. For instance, Baer and Frese (2003) and Black, Carlile, and Repenning (2004) argue that an innovative culture is highly disruptive, changes relationships across functional as well as occupational limits, or causes adjustments to the organizational structure and climate. These results further indicate that different cultural practices have different effects on employees' performance.

There are different Organizational cultures, this culture as a programming of the mind which categories members of the organization in different sections.

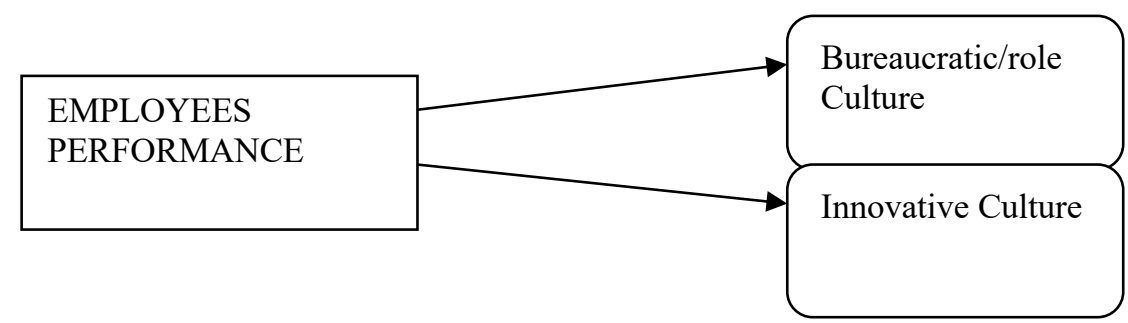

Source: Researchers proposed Model, (2019)

Figure 1: Relationship between Organizational Culture and employee performance

Referring to the diagram value stands as the life of culture in the organization, value cannot do without ethics and moral identity ability of the employees to be creative on the task to be carried out and are able to find out if it suites both the employees and the employers.

\section{Bureaucratic/Role Culture and Employee Performance}

Bureaucratic/role culture is a type of culture that is characterized by bureaucracy as work is coordinated by a manager or a small number of managers at the top. In a role culture orientated organization, structures and systems give protection to subordinates and stability to the organization. The duties and rewards of employee's roles are clearly defined.

Bureaucratic Leadership is an ability to inspire trust and support from the people which is needed to achieve an organizational objective (Kim \& Maubourgne, 1992). Leadership style has been proven to be the determinant of more than one aspect in organization and employees' behavior (Randeree \& Chaudry, 2012). Leadership style is one of the components that can be linked to commitment (Williams \& Hazer, 1986). Leadership behavior affects organizational commitment (Rowden, 2000). Leadership that is practiced by a leader is able to generate commitment from the organization's members. Supportive leadership indirectly and positively influences performance (Montes et al. 2005). Leadership positively correlates to service quality as a measure of 
organization performance (Naceur \& Aisha, 2005). Leadership that is owned by a leader is able to support and encourage organizational performance.

Commitment is used as the mediating variable between an independent variable and dependent variable (Terawatnavong \& Webster, 2005). Commitment is an incentive that directs a behavior toward one or more objectives and generally, this term is conceptualized as a multi-dimensional construct that consists of several antecedents from some correlation and as a consequence, which ranges from some dimensions (Meyer et al., 2002). As a psychological construct in organizational behavior research, commitment has been studied for more than four decades (Alqurashi, 2009).

\section{Innovative Culture and Employee Performance}

Innovative/ entrepreneurship culture is the culture in which organization of activities that makes the employees come together for easy familiarization and socialization as this helps to enhance good relationship among the employees of an organization. Ojo (2010) argued that high levels of risk-taking, dynamism, and creativity characterize an entrepreneurial culture. There is a commitment to experimentation, innovation, and being on the leading edge. This culture does not just quickly react to changes in the environment; it creates change. Individual initiative, flexibility, and freedom foster growth are encouraged and well rewarded in this culture.

Most entrepreneurial ventures start as very small firms with a single purpose: capturing and exploiting the vision of the entrepreneur. A primary challenge for these firms as time passes is moving beyond the start-up phase to become more mature operations, even if they remain small businesses (Blumentritt, Jill \& Lisa, 2005). Doing so often requires standardizing and institutionalizing organizational practices, structuring the contributions of employees, and expanding on the original entrepreneurial proposition that served as the impetus for the firm's creation.

\section{Review of Empirical Studies}

Various studies have been carried out on organizational culture, and employee performance across the globe, including Nigeria and they have mixed and controversial results. Maartje (2018) analyzed the effect of work stress, organization culture and job satisfaction toward employee's performance in Bank Maluku of Ambon Province. The research finding showed that organization culture has positive and significant effect toward performance, work stress has negative effect toward performance and job satisfaction has no effect on employee's performance in Bank Maluku of Ambon Province. Hailin Haimeng and Qiang (2018) examined whether corporate culture promotion affects firm performance in China in terms of firm market value, firm financial performance, and innovation output. They find consistent evidence that corporate culture promotion is negatively related to firm market value, positively related to innovation output and not significantly related to firm financial performance. Inienger and Emem (2018) examined the effect of organizational culture on employee's performance. Content analysis was used for the study and the hypotheses were tested with regression analysis. The study found that the culture of organization is central to either the impressive or unimpressive performance of the employees. Amirreza and Abdollah (2018) studied the impact of High-Performance Work System (HPWS) and the culture of organization on employees' performance in the Iran ministry of education. A survey research design was used. Findings showed that the ministry of education in Iran requires immediate action toward improving performance of members to obtain the desired outcome. Wiwi Widarsih, Madhakomala, and Yetty (2018) determined the effect of organizational culture, personality, and job satisfaction towards employee performance in the Directorate General of Industrial Resilience and International Access Development. The research shows that organizational culture, personality, job satisfaction had a direct positive effect on performance. Eric (2018) determined the effects of organizational culture on employee turnover. The paper was limited to the administrative staff of Private Universities in Ghana. Correlation and regression analysis were done to test the relationship between the organizational culture and employee turnover as well as their impacts. The study found that Bureaucratic Culture (BC) significantly influences employee turnover. Anozie and Ismail (2017) measure and identify how organizational culture affects the performance of its employees. A descriptive research design was used for the purpose of this research work. The result shows 
that organizational culture such as ritual, value, and heroes has a huge and significant impact on employee's performance and through this research, which shows that symbols have little or no impact on employee's performance. Sipahutar, Wibowo., Umar, and Riady (2016) examined the influence of Training, Organizational Culture, Work Motivation, and Job Satisfaction on the Employee Performance at the Defence Industry in the Province of West Java. The method of research used descriptive statistics and Structural Equation Modeling (SEM). The results showed that the Training has a significant impact on Performance; Organizational Culture has a positive and significant impact on Job Performance. Elvis (2015) determined on how the impact of organizational culture on employee job satisfaction can be a source of competitive advantage. Using a case study method, the paper derives quantitative data from the employees of a selected banking company in Oxford, a city in United Kingdom. The empirical findings show that cultural traits of communication, motivation, growth opportunities and supervising support in organizations tend to make employees shift mind set and help the firm in its competitive advantage. Mashal and Saima (2014) ascertained the impact of organizational culture on organizational performance in order to know how the culture of an organization assists in enhancing organizational performance. The findings indicate that all the dimensions of the culture influence the different perspectives of organizational performance. Fakhar, Zahid, and Muhammed (2013) examined the impact of five organizational culture dimensions such as customer service, employee participation, reward system, innovation \& risk-taking, and communication system on employee's job performance of selected software houses in Pakistan. Results showed that all the five dimensions of organizational culture have a significant positive impact on employee's job performance at selected software houses in Pakistan. Aftab, Rana, and Sarwar (2012) examined the impact of four organizational culture dimensions, such as involvement, consistency, adaptability, and corporate mission on role-based performance. Results confirmed that involvement, consistency, adaptability, and corporate mission are positively related to work performance. Sinha and Arora (2012) examined the influence of organizational culture dimensions such as innovation, communication, environment, humanistic workplace, commitment, systems, and result orientation on the business performance of the electric plant in India. Results indicated that all the seven dimensions have a positive and moderate relationship with business performance. Santos and Brito (2012) evaluated the impact toward a subjective measurement model for firm performance reported that the dimensions could not be used interchangeably since they represent different aspects of firm performance and corroborate the idea that stakeholders have different demands that need to be managed independently. Their study used confirmatory factor analyses data from 116 senior Brazilian managers to test its fit and psychometric properties. Mohammad, Rumana, and Saad (2013) examined the impact of organizational culture on employee performance. The study found that organizational culture significantly influences employee performance and productivity in the dynamic emerging context. Hasan and Hamid (2011) studied the link connecting four types of organizational cultures and how it shapes the organization. Results of Correlation and Friedman tests reveal that there is a significant correlation between organizational cultures and learning organizations. Results indicated that all service culture dimensions had a positive effect on organizational excellence. The above literature and empirical studies on organisational culture and employees performance were characterised with mixed reactions from different researchers, some are of opinion that there is a significant positive relationship between organisational culture and employees performance while some had a contrary view between organisational culture and employees performance; However, lack of consensus on the empirical literature calls for further studies on study of this nature.

\section{METHODOLOGY}

\section{Research Design}

This study will adopt survey research design. Survey design involves the use of sample to obtain the opinion of large number of people. It is a research design that study the information gathered from a fraction or percentage of the population.

\section{Population and sample size of the Study}

The population of the study consists of five banks selected deposit money banks quoted on the Nigerian Stock Exchange. The element of the population comprises all the 127 staff of the bank branches across the state. 
Considering the population size wich is not large, the reseachers therefore used all the population size for the study.

\section{Method of data collection}

There is a cover letter to the questionnaire addressed to the respondents, where they were assured that all information provided will be treated with utmost confidentiality and used for the purpose of the research work. The questionnaire were close-ended questions on the research study, structured on a scale of Strongly Agree (SA), Agree (A), Undecided(UN), Disagree (D) and Strongly Disagree (SD); to give the respondents choice of ticking most perceived option. The researchers visited the banks with two assistants to administer the questionnaire to the respondents. The copies of the questionnaire distributed to the respondents were retrieved within 10 working days after administering it to the respondents.

\section{Method of Data Analysis}

Data collected for the study were analyzed by the researcher using frequency counts, mean score and standard deviation. The three hypotheses were tested using simple regression statistical tool with aid of SPSS version 20.0 at $5 \%$ level of significance.

\section{Decision Rule:}

The decision for the hypotheses is to accept the alternative hypotheses if the p-value of the test statistic is less or equal than the alpha and to reject the alternative hypotheses if the p-value of the test statistic is greater than alpha at $5 \%$ significance level.

\section{Model Specification}

The researcher estimated model in the following form:

$\mathrm{EMPFM}_{\mathrm{it}}=\mathrm{a}_{0}+\beta_{1} B U R_{\mathrm{t}}+\sum_{\mathrm{it}}$

$\mathrm{EMPFM}_{\mathrm{it}}=\mathrm{a}_{0}+\beta_{2} I N N_{\mathrm{it}}+\sum_{\mathrm{it}}$

Where:

The dependent variable: Employee performance (EMPFM) and

The independent variables:

$B U R=$ Bureaucratic culture

$I N N=$ Innovative culture

$\mathrm{a}_{0}=$ slope of the model

$\beta_{\mathrm{I}}, \beta_{2}, \beta_{3}$, = coefficient of parameters.

$i$ for the financial year ending at year $t$.

\section{DATA PRESENTATION AND ANALYSIS}

Out of 127 copies of questionnaires distributed, 94 were completed and returned. This represents $74 \%$.

\section{Data Presentation}

Table 1: Analysis of data collected from the targeted respondents

\begin{tabular}{|c|c|c|c|c|c|c|}
\hline $\mathbf{S} / \mathbf{N}$ & STATEMENTS & $\mathbf{S A}$ & $\mathbf{A}$ & $\mathbf{U N}$ & $\mathbf{D}$ & SD \\
\hline & Bureaucratic culture and employees' performance & & & & & \\
\hline 1 & The obligations and rewards of employee's roles are clearly defined. & 39 & 33 & 8 & 12 & 2 \\
\hline 2 & Structures of the organization and systems ensure protection to subordinates. & 30 & 42 & 13 & 7 & 4 \\
\hline 3 & The employers help in stabilizing and developmental structure & 20 & 41 & 8 & 19 & 6 \\
\hline 4 & Operations are being coordinated by the superior for performance appraisal. & 31 & 33 & 3 & 18 & 9 \\
\hline
\end{tabular}




\begin{tabular}{|c|c|c|c|c|c|c|}
\hline 5 & Provides welfare facilities to their employees & 19 & 49 & 11 & 9 & 6 \\
\hline \multirow[t]{2}{*}{6} & There is motivator for high performance. & 21 & 40 & 8 & 20 & 5 \\
\hline & Innovative culture and employees' performance & & & & & \\
\hline 7 & There is quick reaction for operations changes. & 32 & 44 & 0 & 12 & 6 \\
\hline 8 & Individual initiative and flexibility are being encouraged & 23 & 37 & 5 & 22 & 7 \\
\hline 9 & Ensure the development of personal qualities such as creativity. & 22 & 49 & 7 & 11 & 5 \\
\hline 10 & There is room for togetherness, familiarization and socialization & 30 & 42 & 0 & 18 & 4 \\
\hline 11 & Commitment to experimentation, innovation, and being on the leading edge. & 28 & 37 & 8 & 21 & 0 \\
\hline \multirow[t]{2}{*}{12} & Synergy between employees and organization & 25 & 40 & 5 & 19 & 5 \\
\hline & Employee Performance & & & & & \\
\hline 13 & Build suitable communication and capability & 30 & 46 & 2 & 10 & 6 \\
\hline 14 & Quantity enhances & 23 & 37 & 5 & 22 & 7 \\
\hline 15 & Conservation to manage uncertainty & 25 & 49 & 4 & 11 & 5 \\
\hline 16 & Interpersonal relationship and achieve the needed organizational commitment & 32 & 42 & 0 & 16 & 4 \\
\hline 17 & Increase in the employee productivity & 27 & 38 & 8 & 20 & 1 \\
\hline 18 & Quality of services to customers & 27 & 35 & 5 & 24 & 3 \\
\hline
\end{tabular}

\subsection{Test of Hypotheses (Null)}

\section{Hypothesis One}

Ho2: Bureaucratic culture does not significantly affect employee performance of deposit money banks.

In testing this hypothesis, questions 1 to 6 that contain in table 1 were used.

Table 2: ANOVA $^{\mathrm{a}}$

\begin{tabular}{|rl|r|r|r|r|r|}
\hline Model & & Sum of Squares & df & Mean Square & \multicolumn{1}{c|}{ F } & \multicolumn{1}{c|}{ Sig. } \\
\hline \multirow{3}{*}{1} & Regression & 28630.364 & 1 & 28630.364 & 133.281 & $.001^{\mathrm{b}}$ \\
& Residual & 644.436 & 3 & 214.812 & & \\
& Total & 29274.800 & 4 & & & \\
\hline
\end{tabular}

a. Dependent Variable: Employee performance

b. Predictors: (Constant), Bureaucratic

Table 3: Coefficients ${ }^{\mathrm{a}}$

\begin{tabular}{|c|c|c|c|c|c|c|}
\hline \multirow{2}{*}{\multicolumn{2}{|c|}{ Model }} & \multicolumn{2}{|c|}{ Unstandardized Coefficients } & \multirow{2}{*}{$\begin{array}{c}\text { Standardized } \\
\text { Coefficients } \\
\text { Beta }\end{array}$} & \multirow[t]{2}{*}{$\mathrm{t}$} & \multirow[t]{2}{*}{ Sig. } \\
\hline & & $\mathrm{B}$ & Std. Error & & & \\
\hline \multirow{2}{*}{1} & (Constant) & 12.411 & 10.889 & & 1.140 & .337 \\
\hline & EMPFM & .890 & .077 & .989 & 11.545 & .001 \\
\hline
\end{tabular}

a. Dependent Variable: Employee performance

In table 2 , it reveals that the p-value is 0.001 indicates that the hypothesis is statistically significant at level of significance $(5 \%)$; hence $p$-value of the test statistic is less than alpha value.

In table 3, the regressed coefficient correlation result shows that an evaluation of the employee performance of the explanatory variable (Beta Column) shows that Bureaucratic culture is significant (Sig.=0.989).

Since p-value of the test statistic is less than alpha, we, therefore, reject null hypotheses and uphold alternative hypothesis which state that the bureaucratic culture has significant affect employee performance of deposit money banks. 


\section{Hypothesis Two}

Ho2: Innovative culture does not significantly affect employee performance of deposit money banks. In testing this hypothesis, questions 7 to 12 that contains in table 1 were used.

Table 4: ANOVA $^{\mathrm{a}}$

\begin{tabular}{|rl|r|r|r|r|r|}
\hline Model & & Sum of Squares & df & Mean Square & \multicolumn{1}{c|}{ F } & \multicolumn{1}{c|}{ Sig. } \\
\hline \multirow{2}{*}{1} & Regression & 35923.147 & 1 & 35923.147 & 4977.120 & $.000^{\mathrm{b}}$ \\
& Residual & 21.653 & 3 & 7.218 & & \\
& Total & 35944.800 & 4 & & & \\
\hline
\end{tabular}

a. Dependent Variable: Employee performance

b. Predictors: (Constant), Innovation

Table 5: Coefficients ${ }^{\mathrm{a}}$

\begin{tabular}{|c|c|c|c|c|c|c|}
\hline \multirow{2}{*}{\multicolumn{2}{|c|}{ Model }} & \multicolumn{2}{|c|}{ Unstandardized Coefficients } & \multirow{2}{*}{$\begin{array}{c}\begin{array}{c}\text { Standardized } \\
\text { Coefficients }\end{array} \\
\text { Beta }\end{array}$} & \multirow[t]{2}{*}{$\mathrm{t}$} & \multirow[t]{2}{*}{ Sig. } \\
\hline & & B & Std. Error & & & \\
\hline \multirow{2}{*}{1} & (Constant) & .350 & 1.996 & & .175 & .872 \\
\hline & EMPFM & .997 & .014 & 1.000 & 70.549 & .000 \\
\hline
\end{tabular}

a. Dependent Variable: Employee performance

In table 4 , it reveals that the p-value is 0.000 indicates that the hypothesis is statistically significant at level of significance (5\%); hence, $\mathrm{p}$-value of the test statistic is less than alpha value.

In table 5, the regressed coefficient correlation result shows that an evaluation of the employee performance of the explanatory variable (Beta Column) shows that innovative culture is significant (Sig. $=1.000)$.

Since p-value of the test statistic is less than alpha, we, therefore, reject null hypotheses and uphold alternative hypothesis which stated that innovative culture has significant affect employee performance of deposit money banks

\section{Discussion of Findings}

Bureaucratic culture: based on findings, was found to affect positively on our dependent variable, employee performance. This effect was statistically significant. This finding, therefore, supports our aprori expectation and the findings of Rambo and Orwa (2018) Maartje (2018); Eric (2018) and negates the view of Anozie and Ismail (2017).

Innovative culture: based on findings, was found to affect positively on our independent variable, employee performance, but this effect was statistically significant. This finding, therefore, supports the finding of Inienger and Emem (2018) Mohammad, Rumana, and Saad (2012) and negates our aprori expectation and the view of AlEnezi (2011).

\section{Conclusion and Recommendation}

This study examined the effect of organizational culture on the performance of Nigerian deposit money banks. The study found that bureaucratic culture and innovative culture has a positive influence on the dependent variable (employee performance). The study has identified the specific types of organizational cultures that facilitate employee commitments towards achieving the performance of their organization. The outcome of this study indicates that all the organizational culture is most effective in all ramifications. However, the level of motivation has the greatest effect on employee performance, meaning that employee motivation must be the organizational priority even can be improved through suitable communication between the management and the employees. Conclusively, the findings show that various organizational culture influences the different 
perspective of organizational performance. Based on the outcome of the study, it recommended that deposit money banks management should develop cultures that will enhance performance having the interest of their customers and employees.

\section{References}

Al-Matari, E. M., \& Omira, B. (2017). The mediating effect of organizational commitment on the relationship between organizational culture and organizational performance in the public sector: evidence from KSA. International Journal of Business \& Management Science, 7(1), 67-77.

Alqurashi, S.(2009). An investigation of antecedents and consequences of organizational commitment among public employees in Saudi Arabia. Ph.D. Symposium 23-24 March

Anitha, J. (2014). Determinants of employee engagement and their impact on employee performance. International Journal of Productivity and Performance Management, 63(3), 308323.https://doi.org/10.1108/IJPPM-01-2013-0008

Aktaş, E., Çiçek, I., \& Kıyak, M. (2011). The effect of organizational culture on organizational efficiency: The moderating role of the organizational environment and CEO values. Procedia-Social and Behavioral Sciences, 24(1), 1560-1573.

Alvesson, M. (2002). Understanding Organizational Culture. SAGE Publications

Amirreza, S., \& Abdollah A.(2018). The impact of organizational culture and performance work system on employees' performance. International Business Research; 11(6), ISSN 1913-9004 E-ISSN 1913-9012

Anozie, O. P.\& Ismail, N. (2016).Effects of organizational culture on employees performance: case of Singapore Telecommunication. International Journal of Accounting \& Business Management. 4 (1), www.ftms.edu.my/journals/index.php/journals/ijabm

Blumentritt, T., Jill K.\& Lisa K. G.. (2005). Building an inclusive entrepreneurial culture: effects of employee involvement on venture performance and innovation," The International Journal of Entrepreneurship and Innovation, 6(2), 77-84.

Baer, M., \& Frese, M. (2003). Innovation is not enough: climates for initiative and psychological safety, process innovations, and firm performance. Journal of Organizational Behavior, 24(1), 45-68.

Black, L. J., Carlile, P. R., \& Repenning, N. P. (2004). A dynamic theory of expertise and occupational boundaries in new technology implementation: Building on Barley's study of CT scanning. Administrative Science Quarterly, 49(4), 572-607.

Cheung, S. O., Wong, P. S., \& Wu, A. W. (2011). Towards an organizational culture framework in construction. International Journal of Project Management, 29(1), 33-44.

Damanpour, F., \& Gopalakrishnan, S. (2001).The dynamics of the adoption of product and process innovations in organizations. Journal of Management Studies, 38(1), 45-65.

Durgadevi, R. \& Vasantha, S. (2017). Organizational culture and its impact on employee performance (A Study with Reference to IT Sector Chennai). Indian Journal of Public Health Research \& Development, 8(2).

Detert, J. R., Schroeder, R. G., \& Mauriel, J. J. (2000). A framework for linking culture and improvement initiatives in organizations. Academy of Management Review, 25(4), 850-863.

Eric O. K., (2018). Organizational culture and employee turnover: evidence from Ghana. Journal of Economics, Management and Trade 21(2): 1-11, 2018; Article no.JEMT.39062; ISSN: 2456-9216

Elvis A. (2015). Supportive organizational culture and employee job satisfaction: a critical source of competitive advantage. a case study in a selected banking company in Oxford, a City in the United Kingdom. International Journal of Economics \& Management Sciences 4(7). ISSN: 2162-6359 IJEMS, an open access journal

Ezirim, C.B., Nwibere, B.M., \& Emecheta, B.C. (2012). The influence of corporate culture on organizational commitment: The Nigerian experience. International Journal of Business and Public Administration, 9(3), $155-180$.

Ezekiel, S. N., and Darius, N.I.(2012). The Influence of Corporate Culture on Employee Commitment to the Organization, International Journal of Business and Management, 7(22), 21-28.

Fakhar, S., Zahid, I., \& Muhammad, G. (2013). Impact of organizational culture on employees job performance: an empirical study of software houses in Pakistan, Journal of Business Studies Quarterly, 5(2), 56-64.

Hailin, Z., Haimeng, T. \& Qiang W. (2018). The effect of corporate culture on firm performance: Evidence from China. China Journal of Accounting Research11 (2018) 1-19.

Higgins, J. M., \& McAllaster, C. R. A. I. G. (2002). Want innovation? Then use cultural artifacts that support it. Organizational Dynamics, 31(1), 74-84.

Gu, V. C., Hoffman, J. J., Cao, Q., \& Schniederjans, M. J. (2014). The effects of organizational culture and environmental pressures on IT project performance: A moderation perspective. International Journal of Project Management, 32(7), 1170-1181. 
Isa, M. F. M., Ugheoke, S. O. \& Noor, W.S. W. M. (2016). The influence of organizational culture on employees' performance: evidence from Oman. Journal of Entrepreneurship and Business E-ISSN: 2289-8298.DOI: 10.17687/JEB.0402.01

Inienger, C. C. \& Emem, U. (2018). The impact of organizational culture on employee's performance in public sector. International Business Research; 11(6); ISSN 1913-9004 E-ISSN 1913-9012.

Iliuta, D. O. (2014). The link between organizational culture and performance management practices: A case of IT companies from Romania. Annals of Faculty of Economics, 1(1), 1156-1163.

Joo, B. K. B., \& Lim, T. (2009). The effects of organizational learning culture, perceived job complexity, and proactive personality on organizational commitment and intrinsic motivation. Journal of Leadership \& Organizational Studies, 16(1), 48-60.

Joo, B. K., \& Shim, J. H. (2010). Psychological empowerment and organizational commitment: The moderating effect of organizational learning culture. Human Resource Development International, 13(4), 425-441.

Kotter, J., \& Heskett, J. (1992). Corporate culture and performance. New York: Free Press.

Klehe, U. C., \& Anderson, N. (2007). The moderating influence of personality and culture on social loafing in typical versus maximum performance situations. International Journal of Selection and Assessment, 15(2), 250-262.

Kim, A. \& Maubourgne, R.A. (1992). Parables of leadership. Harvard Business Review. July-August, p. 123.

Kim Jean Lee, S., \& Yu, K. (2004). Corporate culture and organizational performance. Journal of managerial psychology, 19(4), 340-359.

Mobley, W. H., Wang, L., \& Fang, K. (2005). Organizational culture: measuring and developing it in your organization. Harvard Business Review China, March 2005, 128-139.

Mohammad J. U., Rumana, H.L. \& Saad M. M. H. (2013).Impact of organizational culture on employee performance and productivity: a case study of telecommunication sector in Bangladesh. International Journal of Business and Management; 6(2). ISSN 1833-3850 E-ISSN 1833-8119.

Mashal A. \& Saima, S. (2014).The impact of organizational culture on organizational performance: a case study of telecom sector. Global Journal of Management and Business Research: Administration and Management;14(3) Version 1.0.

March, J.G, \& Simon, H.A (1997). Organizations. John Wiley and Sons, New York.

Montes, J. L., Moreno, A. R., \& Morales, V. G. (2005). Influence of support leadership and teamwork cohesion on organizational learning, innovation and performance: an empirical examination. Technovation 25: 1159 - 1172 Elsevir

Martin, J. (2005). Organizational behavior and management (3rd ed). London: Thompson learning.

Meyer J. P., Stanley, D.J., Herscovitch, L., \& Topolnytsky, L.(2002). Affective, continuance, and normative commitment to the organization: a meta-analysis of antecedents, correlates, and consequences. Journal of Vocational Behavior, Vol. 61, pp. 20-52.

Naceur, L. \& Aisha, J. \& Rasasi. A.L. (2005). Transformational leadership and service quality in UAE hospitals, Managing Service Quality, 15(1). pp. 70-8.

Neil, J. (2009). Exploring research: New Jersey: Pearson Education International, Inc.

Ojo O. (2010). Organizational culture and corporate performance: Empirical evidence from Nigeria. Journal of Business System, Governance and Ethics.5(2):1-12.

Olaigbe, T. A., Unachukwu, J. C. \& Oyewole, F. A. (2018).Organizational culture and its influence on the performance of Nigerian insurance industry. International Journal of Innovative Finance and Economics Research 6(1):75-83,

Ogbonna, E., \& Harris, L. (2000). Leadership style, organizational culture and performance: empirical evidence from UK Companies. International Journal of Human Resources Management.

Quinn, K. S. C., \& Robert, E. (2011). Diagnosing and changing organizational culture: Based on the competing values framework. John Wiley \& Sons.

Aftab, H., Rana, T. \& Sarwar, A. (2012). An Investigation of the Relationship between Organizational Culture and the Employee ${ }^{e e}$ s Role Based Performance: Evidence from the Banking Sector. International Journal of Business and Commerce 2(4), 1-13.

Robbins, S. (2005). Organizational Behavior, (13th ed.), New Jersey: Prentice Hall Inc.

Romi I.(2018). The impact of organizational culture and leadership style on job satisfaction and employee performance. Journal of Advanced Management Science Vol. 6, No. 1,

Randeree K. \& Chaudhry. (2012). Leadership - style, satisfaction and commitment An exploration in the United Arab Emirates' construction sector. Journal Engineering, Construction and Architectural Management. 19(1).

Rowden, R. W. (2000). The relationship between charismatic leadership behaviors and organizational commitment. The Leadership and Organizational Development Journal. 21(1).

Robbins, S. P. \& Sanghi, S. (2007). Organizational behavior, Pearson education, New Delhi.

Schein EH (2010) Organizational Culture and Leadership. Jossey-Bass, San Francisco, USA. 
Shahzad, F., Iqbal, Z., \&Gulzar, M. (2013). Impact of Organizational Culture on Employees Job Performance: An Empirical Study of Software Houses in Pakistan. Journal of Business Studies Quarterly, 5(2), 56-64

Silverthorne, C. (2004). The impact of organizational culture and person-organization fit on organizational commitment and job satisfaction in Taiwan. Leadership \& Organization Development Journal, 25(7), $592-$ 599.

Sipahutar, H., Wibowo., Umar, H., \& Riady, H., (2016). Influence of training, organizational culture, work motivation, and job satisfaction on the employee performance at defence industry in the Province of West Java, Indonesia”. International Journal of Advanced Scientific Research \& Development (IJASRD), 03 (04/III), pp. $170-186$.

Schein, E. M. (2014). Organizational culture and leadership (3rd ed.). Jossy-Bass.

Stoica, M., Liao, J., \& Welsch, H. (2004). Organizational culture and patterns of information processing: The case of small and medium-sized enterprises. Journal of Developmental Entrepreneurship, 9(3), 251.

Santos, J.B., \& Brito, L.A. (2012). Toward a Subjective Measurement Model for Firm Performance. BAR Rio de Janeiro, 9(6),95-117.

Sinha, A., \& Arora, B. (2012). Fit between Organizational Culture and Business Excellence: A Case Study of Heavy Electrical Equipment Plant, BHEL. Vikalpa: The Journal For Decision Makers, 37(3), 19-27.

Terawatanavong, C. \& Webster, C. M., (2005). Organizational members' commitment to professional associations. Conference: Business Interaction, Relationships and Networks. ANZMAC

Tseng, S. M. (2010). The correlation between organizational culture and knowledge conversion on corporate performance. Journal of Knowledge Management, 14(2), 269-284.

Wallach, E. J. (1983). Individuals and organizations: The cultural match. Training and Development Journal, 37(2), 29-36

Yiing, L. H., \& Ahmad, K. Z. B. (2009). The moderating effects of organizational culture on the relationships between leadership behaviour and organizational commitment and between organizational commitment and job satisfaction and performance. Leadership and Organization Development Journal, 30(1), 53-86.

Zehir, C., Ertosun, Ö. G., Zehir, S., \& Müceldili, B. (2011). The effects of leadership styles and organizational culture over firm performance: Multi-National companies in İstanbul. Procedia- Social and Behavioral Sciences, 24(1), 1460-1474. 